\title{
A Linguistic Forensic Analysis on Sukmawati's "Ibu Indonesia" Poem as been Accused of Insulting Islam
}

\author{
Muhammad Badrus Siroj ${ }^{\mathbf{1}}$ and Sailal Arimi ${ }^{2}$ \\ \{badrussiroj@mail.unnes.ac.id, sailal_arimi@ugm.ac.id\} \\ ${ }^{1}$ Faculty of Languages and Arts, Universitas Negeri Semarang, \\ ${ }^{2}$ Faculty of Humanities, Universitas Gadjah Mada,
}

\begin{abstract}
The objective of this research is to examine the report of blasphemy of Sukmawati's controversial "Ibu Indonesia" poem from analysis of lexical semantic, pragmatic and sociolinguistic viewpoint. Based on the poem and its contextual data after the case reported, semantic features, content analysis, and Stimulus-Response-Feedback depicted interrelation between the poem and following statements around it. The results of the analysis show that there are negative and positive elements in the verse of poem and accompanying statements. These elements include 1) intention, 2) awareness, 3) ignorance, 4) culture, and 5) faith. From the results of the study it can be concluded that the poem by Sukmawati in a lexical semantics contain elements of Islamic insulting sentences related to "veil" and "adzan" but are preceded by sentences that contain elements of ignorance (or lack of knowledge). On the other hand, the statement following around the poem has an intentional element and an apology is acknowledged. Culturally, the poem "Ibu Indonesia" contains Javanese cultural values that have long existed and are used by the community before Islamic culture dispersing to the majority of Indonesin people which then offended their islamic faith.
\end{abstract}

Keywords: linguistic forensic analysis, poem "Ibu Indonesia", blasphemy

\section{Introduction}

Blasphemy is interpreted as an expression that implies disrespect towards religion which is indicated by the use of words that are degrading to religion it self [1]. In this research, the alleged blasphemy was analyzed to see which aspects could be considered to lead to negative classification as a form of blasphemy and which elements emphasized the poet's expression of "Ibu Indonesia" towards the glory of Indonesian culture without the intention of insulting religion.

The poem entitled "Ibu Indonesia" was read by the poet, Sukmawati Soekarnoputri, at the 29th Anniversary Anne Avantie Works at the Indonesia Fashion Week 2018 at the JCC Jakarta, March 29, 2018. The poem is one of the texts from a collection of poems with the same title: "Ibu Indonesia" created in 2006. However, the text of the poem caused controversy when it was read in front of the audience of the event. 
From the literary aspect, if the definition of a poem is referred to [2], the poem is a lyric poem that expresses the author's feelings monologically. That means that the author acts as the narrator in the whole text. Based on this background, the problems in this study are 1) whether or not the poem text entitled "Ibu Indonesia" contains elements of insult to Islam; and 2) what linguistic evidence can be used to support or refute it.

This research used a linguistic approach. Analysis of semantic, pragmatic, and sociological psycholinguistic perspectives is applied in this study. As for seeing the purpose of writing the poem, this study employed the forensic linguistic approach. As explained by [3], forensic linguistic studies include oral or written texts which have the potential to contain important evidence of criminal or civil cases. The scope includes linguistic evidence about the identity of the authors of the text, the meaning or purpose of the text, and statements of witnesses or defendants or prosecutors in court.

Poetry manuscripts, from the perspective of forensic linguistics, cannot be separated from the writer's linguistic styles which are the forms of individual variation that he chooses from variations in the literary world and in the language community. In this connection, [4] summarizes the thoughts of various experts into eight social norms relating to the form and use of language: (1) norms of self-esteem, (2) norms of social conventions, (3) norms of barrel use or language variations, (4) social class norms (age, gender, ethnicity, race, etc.), (5) regional norms (geographical location), (6) norms of conditions (goals, topics, readers or listeners, time and place) , (7) norms of social behavior (politeness of language), and (8) norms of language behavior (lexical and grammatical truth).

To explain in detail the question of the meaning, purpose and message of poetry, the forensic linguistic approach supported by the speech act theory of Austin and Searle is applied, supplemented by Grice's principle of cooperation [5].[6]. In speech act theory, speech acts are divided into three actions: acts of locution acts of illocution and acts of perlocution. The act of locution is related to the meaning of the expression which is determined by the combination of the lexical semantics and the grammatical semantics of the expression. Meanwhile, illocutionary acts are related to the intent of the expression so that it can lead to acts of perlocutionary or non-verbal acts as an understanding of the message behind the expression. The Speech Theory is closely related to the Grice Theory of Collaboration Principle which distinguishes three domains: what is "said" and the purpose behind what is said - called implicature and implicature depends on the assumption that the speaker has collaborated or conversational implicature. In connection with the analysis of this poem, the poet is assumed to be the speaker, while the poetist is the speaking partner.

\section{Research Method}

This study employed the Stimulus-Response-Feedback method that describes the relationship between poetry and the author's statement. Data analysis used a forensic linguistic approach that is supported by analytical data from a semantic, pragmatic, and sociological perspective. Data were analyzed based on important elements related to the research topic, namely 1) intention, 2) awareness, 3) ignorance, 4) culture, and 5) faith. 


\section{Results And Discussion}

From the data analyzed by researchers, the first is the Whistle Blower/reporter's view of poetry by Sukmawati. In the view of the reporter, the contents of the poem are considered to be insulting Islam. The full text of the poem in question is presented below.

Ibu Indonesia Aku tak tahu Syariat Islam

(Mother Indonesia I do not know the Islamic Shari'a)

Yang kutahu sari konde ibu Indonesia sangatlah indah

(All I know is that the bun of mother Indonesian is very beautiful)

Lebih cantik dari cadar dirimu

(More beautiful than your veil)

Gerai tekukan rambutnya suci

(Her hair bends are sacred)

Sesuci kain pembungkus ujudmu

(As sacred as the wrapper of your body)

Rasa ciptanya sangatlah beraneka

(The taste of creation is very diverse)

Menyatu dengan kodrat alam sekitar

(Blend with the natural nature around)

Jari jemarinya berbau getah hutan

(His fingers smelled like forest sap)

Peluh tersentuh angin laut

(Sweat touched by the sea breeze)

Lihatlah Ibu Indonesia

(Look at Mother Indonesia)

Saat penglihatanmu semakin asing

(As your eyesight becomes stranger)

Supaya kau dapat mengingat

(So you can remember)

Kecantikan asli dari bangsamu

(The true beauty of your nation)

Jika kau ingin menjadi cantik, sehat, berbudi, dan kreatif

(If you want to be beautiful, healthy, virtuous, and creative)

Selamat datang di duniaku, bumi Ibu Indonesia

(Welcome to my world, the land of Mother Indonesia)

Aku tak tahu syariat Islam

(I do not know the Islamic Shari'a)

Yang kutahu suara kidung Ibu Indonesia, sangatlah elok

(All I know is the voice of Mother Indonesia, so beautiful)

Lebih merdu dari alunan azan mu

(More beautiful than your azan)

Gemulai gerak tarinya adalah ibadah

(The grace of her dance moves is worship)

Semurni irama puja kepada Illahi

(As pure as worship rhythm to the God) 
Nafas doanya berpadu cipta

(The breath of her pray is unified with creation)

Helai demi helai benang tertenun

(Thread by a strand of woven thread)

Lelehan demi lelehan damar mengalun

(Melt of melt of damar flowing)

Canting menggores ayat ayat alam surgawi

(Canting engraves verses of heavenly nature)

Pandanglah Ibu Indonesia

(Look at Mother Indonesia)

Saat pandanganmu semakin pudar

(When your vision fades)

Supaya kau dapat mengetahui kemolekan sejati dari bangsamu

(So that you can know the true goodness of your people)

Sudah sejak dahulu kala riwayat bangsa beradab ini cinta dan hormat kepada ibu Indonesia dan kaumnya

(It has been a long time in the history of this civilized nation to love and respect the Indonesian mother and her people)

\subsection{Linguistic Analysis}

The lines of poetry that allegedly defamed religion by reporters both from various individuals and Islamic social organizations (totalling 28 people) who had previously reported the poet to the Indonesian National Police at least six lines of the poem which contain insults to Islam. Here are the six lines of poetry that are considered to contain intentions of contempt for Islam.

(1) Aku tak tahu Syariat Islam (LINE 1)

(2) Yang kutahu sari konde ibu Indonesia sangatlah indah (LINE 2)

(3) Lebih cantik dari cadar dirimu (LINE 3)

(4) Aku tak tahu syariat Islam (LINE 16)

(5) Yang kutahu suara kidung Ibu Indonesia, sangatlah elok (LINE 17)

(6) Lebih merdu dari alunan azan mu (More melodious than your azan) (LINE 18)

In the reporter's view, the keywords in the six lines of poetry that are considered insulting to Islam are (1) "... sari konde...lebih cantik dari cadar dirimu ...:" (2) "... suara kidung Ibu Indonesia... Lebih merdu dari alunan azan mu" Reporting party's analysis of their claim that there was an insult to Islam (based on these keywords). Linguistically, the "veil" lexicon can be interpreted as a veil covering the face of Muslim women, which in the poem, the value of beauty is considered lower than "bun." In the [7], a description of the meaning of the word "veil" is not mentioned that the veil is part of Muslim clothing. In the dictionary, the word "veil" means 1. n 'head or face cloth (for women); burkak; '2. n. 'table cover fabric; table cloth; sheets (for mattresses). 'However, in the poem, the word "veil" is indeed better interpreted as interpreted by the reporter, the head covering or face cloth commonly used by Muslim women.

This interpretation of the meaning is associated with the context of the 1st and 16th declarative clauses which read "Aku tak tahu Syariat Islam". Therefore, the meaning of the word "cadar" here is related to a veil worn by Muslim women, not other types of veil. The word "sari konde" (as opposed to a "cadar" in [7] is certainly not listed in a single letter because it is not one lexicon but two lexicons: sari and konde. The lexicon sari has several 
meanings, two of which are 'subject matter' or 'essential part.' Meanwhile, konde/condé means 'hair loop; bunny; kundai. 'So, the phrase "sari konde" means the core part of a haircut.

Comparison of "... sari konde ... lebih cantik dari cadar..." made the reporter interpret the poem as poetry that spread hatred or insult to Islam because "cadar" as one of the characteristics (clothing) of Muslims can not be compared with parts (clothing of culture) which are not Islam. In addition, the comparison actually puts "sari konde" which has a more beautiful beauty value rather than the "cadar" itself. If the position of the subject of the clause is reversed to "cadar lebih cantik dari sari konde, it is certain that protests will not arise because the position of Islamic features is placed higher than non-Islamic features. This is an illocutionary act as if the poet wanted to invite the reader not to use the veil because the veil is no more beautiful than the original attributes of Indonesian clothing, one of which is sari konde. In this case, the directive speech act is quite relevant because in principle, in the poem's text, there is a message to make the reader aware of something better than the others: the sari konde is better than the cadar.

The second keyword that made the reporter objected was "suara kidung Ibu Indonesia... lebih merdu dari alunan azan..." The term "azan" in the [7] means 'a call for Muslims to invite people to pray in congregation.' For the reporter, "azan" is a part of Islamic religious activities that cannot be compared to cultures that are not Muslim. An attempt to place an Islamic identity lower than other identities, for some Muslims, can be considered harassment or spread of hatred.

\subsection{Cultural Analysis}

Appreciation for beauty based on the application of the speech act theory of Austin and Searle and Grice's collaboration principle theory (in Sadock 2004: 58-59; in Grundy 2000: 70100) can be explained by the implied message of poetry according to its illusive actions or implicature. In general, the implicit message of the poem "Ibu Indonesia" is an expression of the author's feelings that glorifies the glory of Indonesian culture. Analysis of the message of the poem can be started from the sense of beauty according to the views and observations of the author. Disclosure of a sense of beauty, as long as it does not conflict with laws, regulations and ethics, whether it is a product of a country, religion or culture - there is no harm in being expressed in verbal or nonverbal language (gestures or objects). Conversely, when a sense of beauty is expressed, either explicitly or implicitly and is considered against social rules that apply, then the expression of beauty will cause opposition in society.

The phrase "Syarat Islam" (Islamic Requirements) is used twice, while the phrases "cadar dirimu" and "azan" each are used once. If Indonesian people, nation, culture and nature are personified as a mother, born and raised in Indonesia, she is free to express herself. She may appear as an Indonesian woman who is influenced by Indonesian traditions, Islamic traditions and foreign traditions, as long as they do not violate the legal and social rules of Indonesian society. For example, in Indonesia, not all Muslim women wear a "cadar" when they are in a public place. Their unwillingness to wear the veil is not determined by the consideration that the veil is inappropriate or untrue, but because of their beauty considerations. They feel that bent hair with a bun is part of the beauty of physical appearance as long as it is used in the right situation and place; not on the consideration of right or wrong. When some Indonesian mothers choose bun instead of a veil, it does not mean they show their hatred of the veil, but maybe it is merely a personal consideration on the basis of beauty.

The poem "Ibu Indonesia" consists of four stanzas, twenty-eight lines and 157 words. The verse that mentions the name "Islam" for the first time is the first line: Aku tak tahu Syariat Islam. In fact, this clause if it is not associated with other lines, will not cause a negative 
interpretation. Someone who has no knowledge of something is not to blame. In the following lines, a comparison style is used which reveals the forms of beauty of the Indonesian human style. This kind of comparison that causes controversy over the interpretation of meaning, that is, there are interpreters who assume that the poem has the intention of the author to demean some of the Islamic Shari'a practices instead of the practice of native Indonesian culture. Instead, the poet would say that he had no such intention. Linguistically, both participants have the truth, but both types of interpretation can cause problems.

The first line becomes the core of information and controls the following lines which if it is paraphrased into two forms of modified descriptive text will be as follows. First, the "I" does not have knowledge about the Islamic Shari'a, but he knows the various beauties owned by Indonesian people. Artefacts and styles of beauty (called the words "beautiful", "sacred" and "beautiful") can be seen in the use of "sari konde," "hair bending outlets", "creative taste", "natural nature", "fingers", and "sweat". Secondly, the problem of negative exposure can arise if the first line is contrasted with the following lines. The descriptive paraphrase can be engineered as follows. I do not know the Islamic Shari'a, what I know is the bun used by Indonesian women which is very beautiful, more beautiful than the veil (which is in the Islamic Sharia). Then, the description of bending hair looks sacred, as sacred as a cloth covering the head, can be added that there is an attempt to equalize the female headscarf (head wrap) worn by Muslim women compared to the description of hair that covers the upper part of a woman's body. The following are excerpts of the first verse of the poem "Ibu Indonesia:" (7) Ibu Indonesia Aku tak tahu Syariat Islam Yang kutahu sari konde ibu Indonesia sangatlah indah Lebih cantik dari cadar dirimu Gerai tekukan rambutnya suci Sesuci kain pembungkus ujudmu Rasa ciptanya sangatlah beraneka Menyatu dengan kodrat alam sekitar Jari jemarinya berbau getah hutan Peluh tersentuh angin laut.

\subsection{Elements of Ignorance and Awareness}

In the poem "Ibu Indonesia", the author writes his views on Islam. The Islamic elements offended on the first verse, again on the third verse, especially on the first three lines: //Aku tak tahu syariat Islam (I do not know the Islamic law) // Yang kutahu suara kidung Ibu Indonesia, sangatlah elok (I know the voice of Indonesian mother, so beautiful) // Lebih merdu dari alunan azan mu (More beautiful than your azan) $/ /$.

These three lines are a unit of information which, if put together, can be a compound sentence that has a message that The I does not understand the Islamic Shari'a because maybe his religious knowledge is weak (his acceptance is weak). The more knowledge he has is the elements of Indonesian culture, one of which is about songs. The word "kidung" in this case can represent Indonesian art or culture which has its own beauty values. The values of beauty that have nuances of Indonesia or the Archipelago are also not purely Indonesian, but are the result of acculturation of foreign cultures in ancient times, in terms of religions before the arrival of Islam and Christianity. Unfortunately the beauty of the "suara kidung" is stated to be "more melodious than the azan." Azan as a message of religion cannot be compared to the message of non-religion because both have different statuses; hymns are not always sacred because they depend on the setting and purpose of the chanting; while the call to prayer is always sacred wherever it is recited. Suppose that hymns are also sacred which contain divine messages which are the original beliefs of Indonesia, but azan as an Islamic identity is still taboo when it is juxtaposed or compared with hymn. The level of face threat is more serious in the phrase (this 3rd verse): "suara kidung Ibu Indonesia, ... lebih merdu dari alunan azan mu..." compared to the phrase (1st verse) "...sari konde ... lebih cantik dari cadar dirimu..." The "azan" (as mentioned earlier) for Muslims is certainly one form of Islamic religious 
activity that cannot be criticized or questioned by anyone even though the strains may sound less beautiful, if, for example, recited by an untrained reciter. From the whistleblower's side, the illocutionary act could be concluded that the author of the poem wanted to make a statement that the azan which is usually recited by loudspeakers does not have a beauty value when compared to the chanting of Indonesian sound art.

Beautiful and irresistible perception certainly depends on the audience, because even though all the elements of beauty and substance of the call to prayer have been fulfilled, one might consider the strains to be less beautiful especially to be sung by loudspeakers that can disturb the surrounding community. In this case, it must be realized that the call to prayer is not merely seen in its artistic value but rather in its religious message. For some people, the statement of openness will openly raise a problem because it is considered to denigrate the azan as a form of Islamic religious entity, not merely a work of art. So, the text "... suara kidung Ibu Indonesia, ...lebih merdu dari alunan azan mu... is not intended by the poem to insult the teachings of Islam, but is merely seen in the values of beauty as an extrinsic aspect of religion that is different from Indonesian culture. Here the writer is less careful of the cultural and societal contexts whose religious identity is disturbed. The context when the poem was read by the author, coincided with Indonesia's political contestation, which made it inappropriate. This context can be interpreted as poetry insulting Islam. However, if it is reviewed based on the statements made by the author when giving a response to the community related to the issue, the ignorance becomes biased. The following is the author's statement at the press conference. In statement, Sukmawati knew that people who called on the azan should sound melodious in the phrase "So yes please people who do the task of azan should have a good voice, pleasant to hear". Thus, the author understands the question of azan that is included in Islamic law. It can be said that there is an element of "consciousness" of the author in expressing his opinion.

\section{Conclusion}

The alleged blasphemy on the poem "Ibu Indonesia" written by Sukmawati Soekarnoputri occurs because the poem contains lines in which there is a use of vocabulary that places elements of Islamic religion under the elements of Indonesian culture. Such placement is considered as an expression of humiliation or harassment of Islam by the author of the poem. Two groups of words in the form of sentences are considered as expressions of contempt for Islam: (1) "...sari konde ... lebih cantik dari cadar..... (the bun ... more beautiful than the veil ...)" and (2) "...suara kidung Ibu Indonesia... lebih merdu dari alunan azan mu..." as evidence of forensic text by the reporting party who suspected that the poem was considered to have incited hatred and was in conflict with the Information and Electronic Transactions Law, Article 28, Paragraph 2.

As for the authors, the poetry text contains a statement of ignorance "Aku tak tahu Syariat Islam (I do not know the Shari'a of Islam)" which is expressed twice (in line 1 and line 16). Such self-expression can be considered as part of the text that determines that the author of the poem has no intention of degrading Islam. But in the text of the "apology" statement conveyed by the author after reports from various parties, the element of "ignorance" does not mean not knowing. The writer consciously writes poetry.

His ignorance of Islam, both analyzed from the Speech Act theory and the Principle of Cooperation, is an honest acknowledgement that she has no knowledge of Islam. The author 
does not deal with aspects of Islamic teachings, but she only touches on the surface elements that are related to art and culture. The author does not reject the presence of Islam in Indonesia, but she wants a form of cultural acculturation between Indonesia's native culture and Islam. Proven in the poem, there is a use of positive vocabulary which is a feature of Islam: worship, divine, verses, prayers that are collocated with religious vocabulary derived from Sanskrit as a Hindu characteristic: heavenly and worship. The carefulness of the author of the poem occurs in the neglect of the context outside the language which includes the context of the participant, the context of the situation and cultural context. From the discussion, it can be concluded that in Sukmawati's poem, the semantic lexical contains elements of insulting Islamic sentences related to "cadar" and "azan" although preceded by the phrase "ignorance" about Islamic law. Based on the data outside the poem, the statement "sorry" states that the author is "aware" that the poem can be said to "defile" the religion of Islam.

\section{References}

[1] Sinclair, John. Et al. (Eds.), Collins Cobuild English Language Dictionary. London: William Collins Sons \& Co ltd, 1987

[2] Luxemburg, Jan Van and Bal, Mieke and Weststeijn, Willem G, Tentang Sastra. Jakarta: Intermasa, 1989

[3] Olsson, John and Luchjenbroers, Forensic Linguistics, London and New York: Bloomsbury, 2014

[4] McMenamin, Gerald R, Forensic Linguistics: Advances in Forensic Stylistics, London and New York: CRC Press, 2002

[5] Sadock, Jerrod, "Speech Acts," in Laurence R. Horn and Gregory Ward, The Handbook of Pragmatics, Blackwell, Oxford, pp.53-73, 2004

[6] Grundy, Peter, Doing Pragmatics, Second Edition. London:Hodder Arnold, 2000

[7] Departemen Pendidikan Nasional. 2008. Kamus Besar Bahasa Indonesia Pusat Bahasa, Edisi Keempat. Jakarta: Gramaedia Pustaka Utama

[8] M. A. Khak, "Idiom dalam Bahasa Indonesia: Struktur dan Makna," J. Widyaparwa, vol. 39, no. 2, pp. 141-153, Desember 2011.

[9] H. Kridalaksana, Kamus Linguistik. Jakarta: PT. Gramedia, 1983.

[10] Tim Penyusun Kamus Pusat Pembinaan dan Pengembangan Bahasa, Kamus Besar Bahasa Indonesia, Edisi II C. Jakarta: Balai Pustaka, 1997

[11] M. Halliday and R. Hasan, Language, Context, and Text: Aspect of Language in a SocialSemiotic Perspective, Diterjemahkan ke dalam bahasa Indonesia oleh Asrudin Barori Tou, 1992. Bahasa, Konteks, dan Teks: Aspek-aspek Bahasa dalam Pandangan Semiotik-Sosial. Yogyakarta: Gadjah Mada University Press, 1985

[12] Departemen Pendidikan Nasional. 2008. Kamus Besar Bahasa Indonesia Pusat Bahasa, Edisi Keempat. Jakarta: Gramaedia Pustaka Utama 